\title{
Capillary Electrophoresis of Microbes
}

\author{
Byoung Geoun Moon, Yong-Ill Lee, ${ }^{\dagger}$ Seong Ho Kang,,${ }^{\ddagger}$ and Yongseong Kim* \\ Division of Chemistrv and Chemical Engineering. Kumgnam Chiversin, Masan 631-701, Korea \\ Deparment of Chemistry, Changwon Chiversin. Changw on 6+1-773, Korea \\ ${ }^{\ddagger}$ Department of Chemistry. Chumbuk National University. Jeoniu $561-756$, Korea \\ Received October 9, 2002
}

\begin{abstract}
Direct analysis of microbes such as either gram-positive or gram-negative bacteria without cell lysis was investigated using capillary electrophoresis. Bacteria cells were directly introduced into the microbore fusedsilica capillary then separated under high electric field in less than $15 \mathrm{~min}$. It was found that a proper dispersion of bacteria cells was important for reproducible results. Migration behavior of bacteria at different storage condition was investigated and many unexpected peaks were observed from bacteria stored at room temperature due to the distortion of cells. This phenomenon was attributed to the change of size and shape of the same bacterium and confirmed by the scanning electron microscopic images.
\end{abstract}

Key Words : Capillary electrophoresis, Bacteria, Microbes, Scanning electron microscopy

\section{Introduction}

Direct analysis of bacteria without pretreatment is inportant in the area of diagnosis and profiling of some diseases. evaluation of soil populations for agriculture, bioremediation. and quality control in fermentation processes. ${ }^{1}$

Conventionally. bacteria cells have been lysed to investigate unique genetic materials or cell components. ${ }^{2, \hat{3}}$ However. many cell components such as lipoproteins, glycoproteins, lipids. lipopolysaccharides, and polynucleotides have similar structures in different bacteria. causing many unwanted peaks or negative identifications of bacteria., Fluorescence assay and immunoassay have been introduced and turned out to be efficient. However. the culture of bacteria needs long time and the synthesis of selective antibodies are required before analysis. ${ }^{50}$ Also. the sample pretreatment process is time consuning and nonspecific absorption of antibody can cause negative results. ${ }^{7}$ Matrixassisted laser desorption/ionization (MALDI) mass spectrometry has been employed for the direct analysis of bacteria using specific biomarker ions in the bacteria cell. ${ }^{\S}$ However. vast number of $\mathrm{m} / \mathrm{z}$ peaks was sometimes observed due to many cell constituents. resulting in tough data analỳsis

Capillary electrophoresis (CE) would be a prominent analytical technique for direct analysis of bacteria since it is simple and efficient. ${ }^{9}$ Capillary electrophoresis has been widely applied to organic and inorganic ions as well as colloidal particles. Lately capillary electrophoresis has been used for the analysis of deoxyribonucleic acid (DNA). protein. vinus and bacteria. ${ }^{\text {J.11.12 }}$

In the analysis of intact microbes. capillary electrophoresis showed the successful separation of a tabacco mosaic virus and Lactobacilhus casei ${ }^{13}$ The analysis of four types of human rhinovinus with a surfactant was reported by capillary isoelectric focusing (CIEF) ${ }^{1+}$ Yeast cells with different growth phase showed different isoelectric points. ${ }^{15}$ The cell viability was determined by capillary electrophoresis with the fluore- scence probes. ${ }^{9}$ Bacteria from infected urinary tract were separated using a water-soluble polymer solution. ${ }^{16}$

Certain bacteria have strong affinity to the cell surface of other bacteria due to strong hydrophilic and hydrophobic interactions. Therefore, chains or clusters of bacteria cells tend to be easily formed. In our study, we have investigated the formation of chains or clusters of bacteria and demonstrated the successful separation and detection of intact bacteria. Also. the activities of bacteria at different storage conditions for improved diagnosis were evaluated and confirmed by the analysis of scanning electron microscopic inages.

\section{Experimental Section}

Chemicals. Aerobacter aerogenes, Psetdomonas fhorescens and Micrococcus bisodeikticts were received as freeze-dried (Sigma-Aldrich Co.). Tris(hydroxymethyl)aminomethane (TRIZMA base) boric acid etheylenediaminetetra-acetate (EDTA), por(etlylene)oxide ( $\mathrm{PEO}, \mathrm{Mw}=1.000 .000$ and 400.000). phosphoric acid. potassium hỵdroxide were also purchased from Sigma-Aldrich.

Capillary electrophoresis. Buffer $(4.5 \mathrm{mM}$ Tris. $4.5 \mathrm{mM}$ boric acid. $0.1 \mathrm{mM}$ EDTA. $\mathrm{pH}=8.4$ ) was diluted $8: 1$ by deionzed water. Poly (ethylene)oxide $(\mathrm{Mw}=1,000,000$ or 400.000 ) was dissolved in this buffer at the concentration of $0.5 \%$. The polymer solution was stirred for $2 \mathrm{~h}$. then ultrasonicated for $1.5 \mathrm{~h}$ for complete dispersion. It was further diluted to $0.0125 \%$ and ultrasonicated before the electrophoresis ruming.

Bacteria samples were prepared by dissolving in the $8: 1$ diluted buffer at the concentration of $1 \mathrm{mg} / \mathrm{mL}$. They were precipitated by ultracentrifuge at $12.000 \mathrm{rpm}$ and the supernatant was decanted. They were redissolved in the $8: 1$ diluted buffer and completely dispersed by ultrasonication for $5 \mathrm{~min}$. For the investigation of migration behavior of bacteria depending on age or growth condition. Areobacter 
aerogenes was stored at $0^{\circ} \mathrm{C}$ or at room temperature for 15 days.

Electrophoresis nun was performed by using Beckman PACE 5000. A fused silica capillary (Polymicroteclunology' Co.) with 75 micrometer i.d. was employed for the separation. Total length of the capillary was $27 \mathrm{~cm}$ with the effective length of $20 \mathrm{~cm}$. The capillary was preconditioned by washing with $0.5 \mathrm{~N}$ phosphoric acid for $2 \mathrm{~min}$. deionized water for $3 \mathrm{~min}$. $1 \mathrm{~N}$ potassium hydroxide for $2 \mathrm{~min}$. then $0.0125 \% \mathrm{PEO}$ nunning buffer for $2 \mathrm{~min}$. Pre-electrophoresis nun before bacteria sample injection was underwent for 5 min for the stabilization of baseline. Each bacteria sample was injected by $0.5 \mathrm{psi}$ for $10 \mathrm{~s}$ and run at $10 \mathrm{kV}$. A UV absorption detection at $214 \mathrm{~nm}$ was employed.

Scanning electron microscopy (SEM). The images of bacteria stored at $0^{\circ} \mathrm{C}$ and at $23{ }^{\circ} \mathrm{C}$ were compared by the scanning electron microscopy. Initially bacteria cells were fixed by glutaraldehyde $20 \%$ solution and stored for $24 \mathrm{~h}$. Each sample was then washed twice with $60 \% .70 \% .80 \%$. $90 \%$ and $95 \%$ of methanol. Ultracentrifuge with $12.000 \mathrm{rpm}$ were performed between wash steps and the supernatant was decanted. The SEM image was taken by Hitachi S-4200 at $10 \mathrm{kV}$ and magnified by 20000 times. The resolution at 10 $\mathrm{kV}$ was around $2.0 \mathrm{~mm}$ and a cold-cathode field emission was employed for the generation of the second electron.

\section{Results and Discussion}

Table 1 shows the characteristics of bacteria employed in this work. Size and shape are so critical in electrophoresis since the mobility of each bacterium under electric field is determined by those factors. As shown in Table 1. Pseudomonas fluorescens and Aerobacter aerogenes have flagella. while Micrococcus hisodeikticus is non-motile. Most of bacteria are less than 2 micrometer in diameter. The shape of bacteria is unique (rod. sphere spheroidal), and Gram staining is either positive or negative. In general bacteria are amphoteric and sensitive to $\mathrm{pH}$. ionic strength. and living enviromment. However. intra- and extracellular components in those bacteria cells are so diverse that the separation of bacteria under electric field has to be carefully controlled. Certain bacteria have strong affinity to organic or inorganic surface. substances from soil. and the cell surface of other kinds of bacteria. Therefore chains or clusters of bacteria cells tend to be easily formed. The formation of chains or clusters makes the electrophoretic separation of bacteria less feasible since they produce many unwanted peaks in the electropherogram.

Figure 1 shows the electrophoretic separation of Micrococcus hrodeikticus and Pseudomonas fhorescens. Without proper dispersion, bacteria tend to form many different sizes of chain or cluster resulting in several strong peaks with different migration times as shown in Figure la and lc. When the bacteria samples were well dispersed with ultrasonication for $5 \mathrm{~min}$ before injection. Micrococcus bsodeikticus and Psetidomonas fluorescens showed a strong peak with the great suppression of chain or cluster formation (Figure $\mathrm{lb}$ and $\mathrm{ld}$ ). We found that ultrasonication was required before every injection of bacteria samples. meaning that the formation of chains or clusters are favorable under normal buffer condition. ${ }^{9}$

Figure 2 shows the separation of mixed Micrococcus /ysodeikticus and Psendomonas fhorescens at $8: 1$ diluted running buffer with $0.0125 \% \mathrm{PEO}(\mathrm{Mw}=1.000 .000)$. As shown in Table 1. Micrococcus bsodeikticus is non-motile. while Pseudomonas fluorescens has flagella. The shape of Micrococcus bysodeikticus is close to sphere. while Psettomonas fluorescens is rod-like. Baseline resolution for the mixed Micrococcus hsodeikticus and Psetdomonas fluorescens sample was obtained with high separation efficiency.

As compared to Figure $\mathrm{lb}$ and $\mathrm{ld}$. different migration times were observed for Micrococcus bysodeikticus and Psetdomonas fluorescens in Figure 2 compared to in Figure 1. and this phenomenon can be attributed to a decreased concentration of nuning buffer. We believe that a lower buffer concentration changed the local environment of bacteria cell surface. generating mobility shifts and improved resolution. Also. many bacteria can secret proteins. enzymes. and other small biomolecules in the buffer. Therefore, the surface properties of mixed bacteria may be altered. resulting in interference of microbe analysis or migration time shifts. Even. the mobility shift at the same nunning buffer concentration but different sample buffer concentration was reported ${ }^{16}$ for the detection of Escherichia coli in urinary tract Escherichia coli in concentrated urine had slower mobility than in diluted urine. and the use of internal standard was suggested for the identification of bacteria or comparing electropherograms

In order to investigate variations of shape or size of microbes caused by the age or changes in growth conditions. Aemobacter

Table 1. The classes and properties of bacteria

\begin{tabular}{|c|c|c|c|c|c|c|c|}
\hline Bacterilum & $\begin{array}{l}\text { Grann } \\
\text { stain }\end{array}$ & $\begin{array}{c}\text { Diameter } \\
(\mu m)\end{array}$ & Form & Flagella & $\begin{array}{l}\text { Optimum } \\
\text { growth } \\
\text { Temperature }\end{array}$ & $\begin{array}{l}\text { Aerobe or } \\
\text { anaerobe }\end{array}$ & Existence in nature \\
\hline $\begin{array}{r}\text { Psewdontonas } \\
\text { fhrorescens }\end{array}$ & negative & $0.5-1$ & slightly curved rods & $\begin{array}{l}\text { one or several } \\
\text { flagella }\end{array}$ & $25-30^{\circ} \mathrm{C}$ & $\begin{array}{l}\text { strict } \\
\text { aerobes }\end{array}$ & soil and water \\
\hline $\begin{array}{l}\text { Aerobacter } \\
\text { aerogenes }\end{array}$ & negative & $0.5-1$ & motile rods & $\begin{array}{l}4-6 \text { peritrichous } \\
\text { flagella }\end{array}$ & $\leq 37^{\circ} \mathrm{C}$ & $\begin{array}{l}\text { facultative } \\
\text { aerobes }\end{array}$ & $\begin{array}{c}\text { faces of man other animal, } \\
\text { soil, water, sewage }\end{array}$ \\
\hline $\begin{array}{l}\text { Mficrococcus } \\
\text { hrsodeihticus }\end{array}$ & positive & $1-2$ & $\begin{array}{l}\text { spheres, irregular cluster } \\
\text { or regular packets }\end{array}$ & nommotile & $30^{\circ} \mathrm{C}$ & $\begin{array}{c}\text { strict } \\
\text { aerobes }\end{array}$ & $\begin{array}{c}\text { skin of man and other animal, } \\
\text { soil, dust, water }\end{array}$ \\
\hline
\end{tabular}



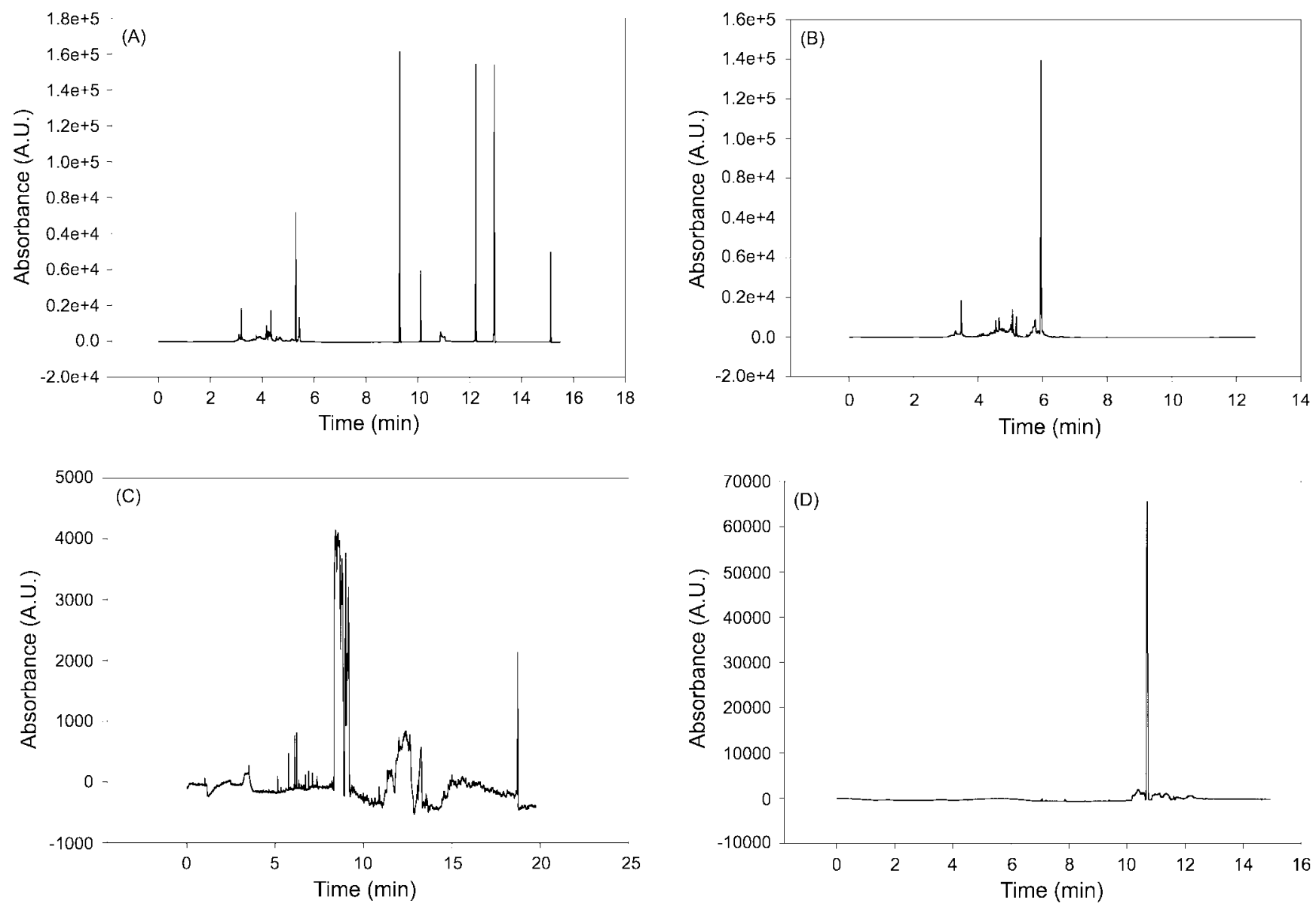

Figure 1. Electropherograms of iffrococcus tysodeihticus (Fig. Ia and Ib) and Pseudonomas fhorescens (Fig. Ic and Id). Bacteria samples were dissolved in $8: 1$ diluted $0.05 \mathrm{X}$ TBE buffer at the concentration of $1.0 \mathrm{mg} / \mathrm{mL}$. For figlue $1 \mathrm{~b}$ and $1 \mathrm{~d}$, bacteria were dispersed in an ultrasonic bath for $5 \mathrm{~min}$. For figure la and $\mathrm{lc}$, bacteria were injected into the column without the treatment by ultrasound. Running buffer $(\mathrm{ph}=8.4)$ was composed of $4.5 \mathrm{mM}$ Tris, $4.5 \mathrm{mM}$ boric acid, $0.1 \mathrm{~mm}$ EDTA, and $0.0125 \%$ poly (ethy lene oxide $(\mathrm{Mw}=1,000,000)$. Other condition: fused silica capillary, 75 micrometer i.d., $27 \mathrm{~cm}$ total length, $20 \mathrm{~cm}$ effective length, $+10 \mathrm{kV}$ nuning voltage, room temperature, pressure injection at $0.5 \mathrm{psi}$. for $10 \mathrm{~s}$.

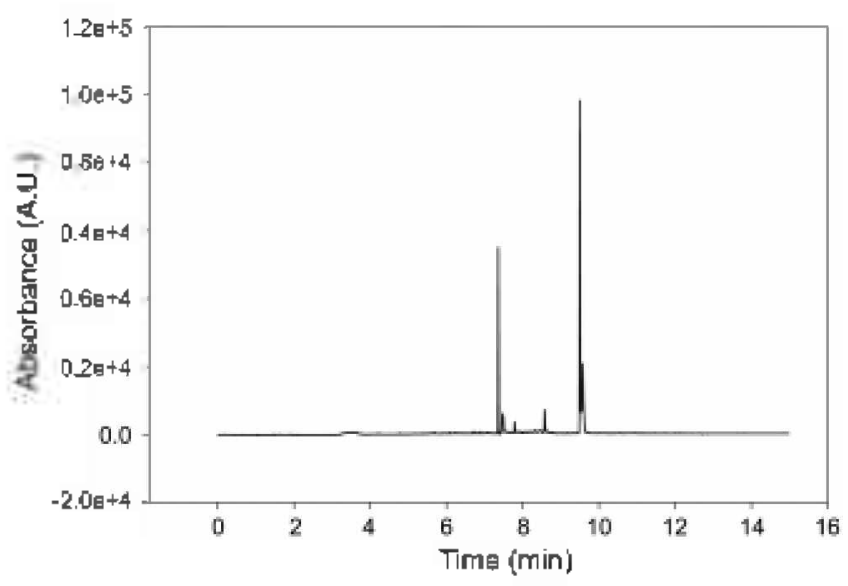

Figure 2. Electropherogranns of mixed Micrococcus lvsodeihticus and Pseudomonas faorescens. Each bacterium concentration was $0.5 \mathrm{mg} / \mathrm{mL}$. Running butter was further diluted $8: 1$ from that used in figure 1 . Other conditions are the same as in figure 1.

aerogenes was stored at two different temperature conditions and compared as shown in Figure 3. The variation may make it difficult to identify microbes. however. the analysis of bacteria at different growth stages may be advantageous in obtaining information regarding the behavior of microbes under high electric field.

When Aerobacter aerogenes was stored at $0^{\circ} \mathrm{C}$ (completely' donmant), a strong peak with several minor peaks was observed (Figure 3a). However. when it was stored at room temperature (slightly active) for 15 days. many noticeable peaks were obtained (Figure $3 \mathrm{~b}$ ) indicating the fomation of chains or clusters. Since bacteria are living organism. they can grow even under unculturable conditions. It was known that the size of bacteria became smaller under those conditions probably due to the secretion of cellular components. ${ }^{17}$ The change of size and shape and the fonmation of chains or clusters would cause the mobility shifts and unwanted peaks. This gives the idea that the identification and separation of microbes should be taken in consideration of growth stage and storage condition. As suggested by Amstrong. ${ }^{1.16}$ the use of internal standards would produce the reproducible results for both qualitative and quantitative analysis of microbes.

To confirm the changes of size and shape at different storage conditions. scanuing electron microscopic images were taken for Aerobacter aerogenes as shown in Figure ta 

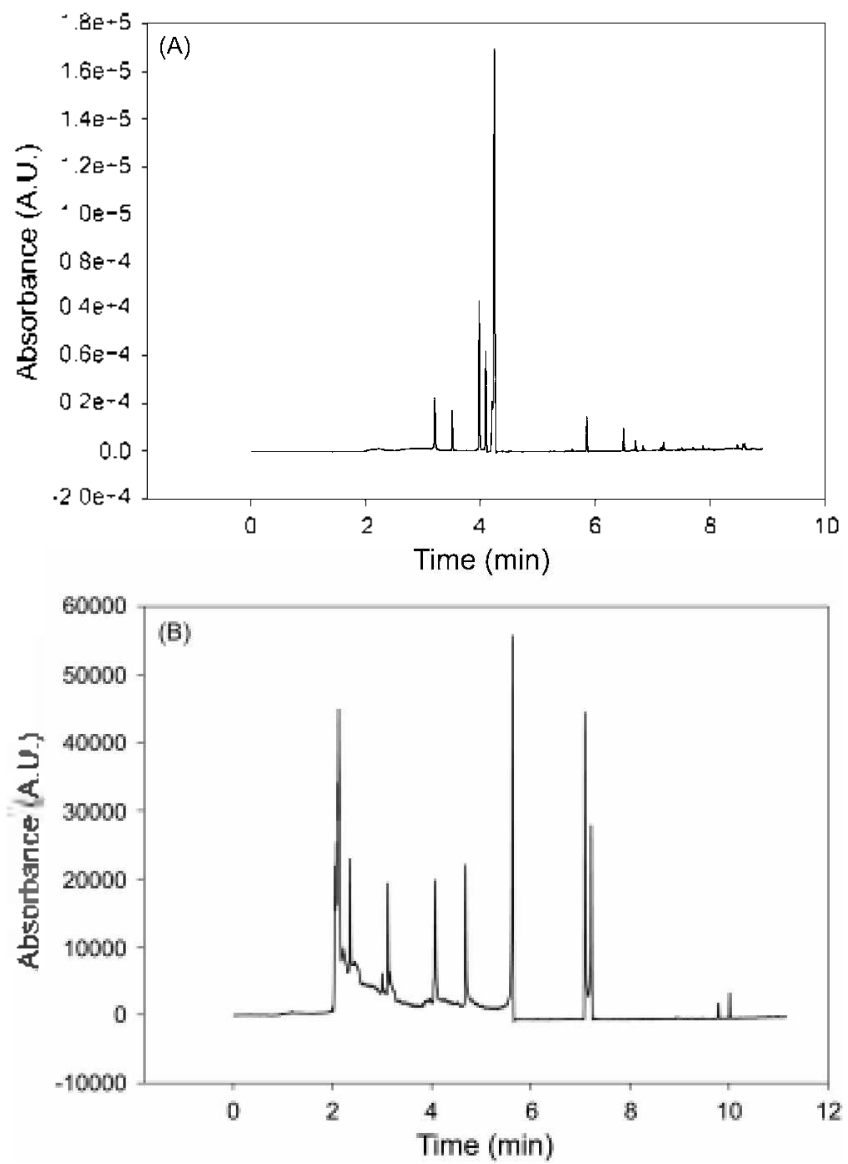

Figure 3. Electropherograms of Aerbbacter aerogenes stored at 0 ${ }^{\circ} \mathrm{C}$ (Fig. 3a) or stored at room temperature for 15 days (Fig. 3b). Fonmation of more chains or clusters was observed with Aerobacter aerogenes stored at room temperature ( $\mathrm{Fig} . \mathrm{Bb}$ ). For tigure $3 \mathrm{a}$ and 3 b, bacterium sample was dispersed by ultrasonication for $5 \mathrm{~min}$ before injection.

and $4 \mathrm{~b}$. Figure $4 \mathrm{a}$ and $4 \mathrm{~b}$ correspond to figure $3 \mathrm{a}$ and $3 \mathrm{~b}$. respectively: Compared to figure $4 \mathrm{a}$. figure $4 \mathrm{~b}$ (Aerobacter aerogenes stored at room temperature for 15 days) shows distorted shapes with uneven sizes. This change would cause many spurious peaks as shown in figure $3 \mathrm{~b}$ since the electrophoretic mobility is the function of size and shape. SEM images clearly suggest that the growth condition should be carefully considered to separate and identify' bacteria.

\section{Conclusions}

Microbes with different size and shape were separated using capillary electrophoresis without cell lysis. We found that a proper dispersion of microbes before injection to the capillary inlet was critical for reproducible results. Otherwise. unwanted peaks due to the formation of chains for clusters were observed. Also the storage condition was turned out to be important for the analysis of bacteria. Electropherograms of bacteria stored at $0^{\circ} \mathrm{C}$ or at room temperature showed different migration behavior and it could be attributed to the change of size and shape at differ-
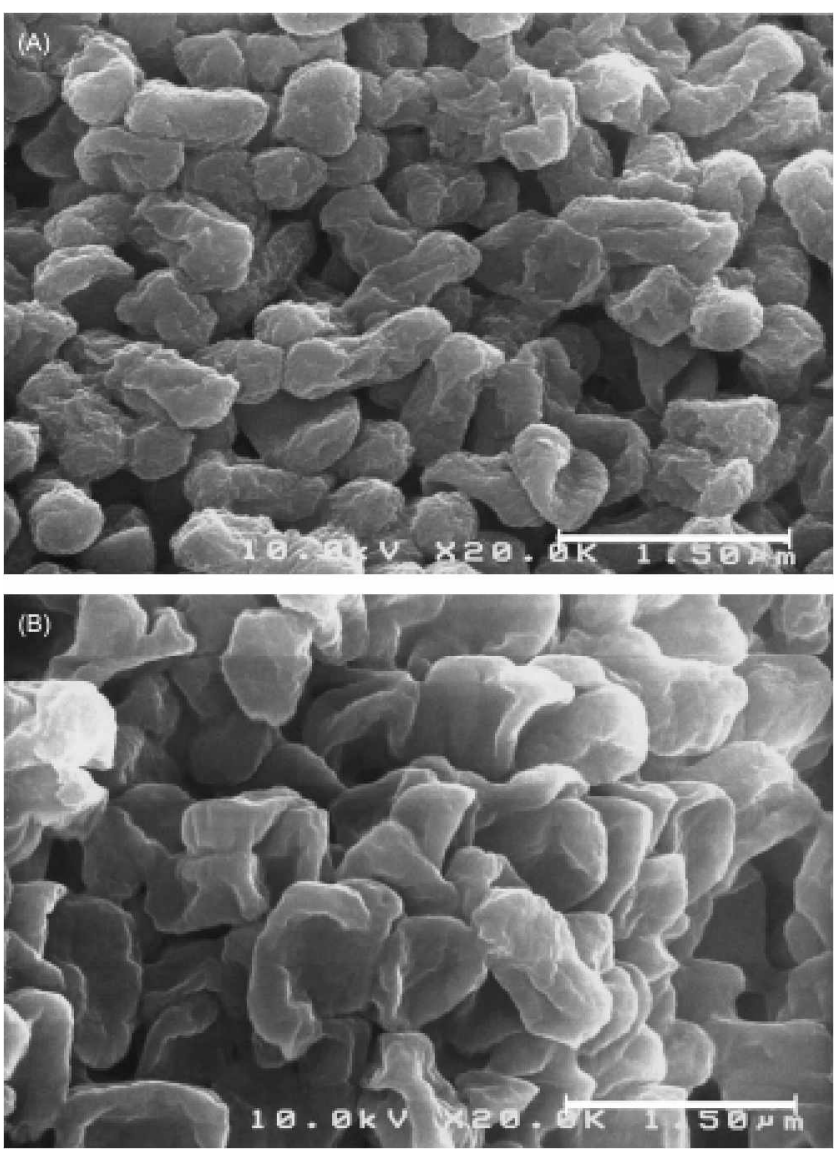

Figure 4 . The scaming electron microscopic images of Aerobacter aerogenes. Figure ta and $4 b$ corespond to figure $3 a$ and $3 b$. respectively. SEM was performed using Hitachi S-4200 at $10 \mathrm{kV}$ and magnified 20,000 times. For the preparation of bacteria, see the experimental section.

ent environment. This change was confirmed by analysis of the scanning electron microscopic images.

We believe that direct analy sis of pathogenic microbes by capillary electrophoresis would be useful since it shows the great potential as a fast and simple diagnosis tool. Study toward the separation of bacteria with cell fixation and/or using a lab-on-a-chip tecluique is under progress.

Acknowledgment. This work was supported by grant No. R05-2001-000-00238-0 from the Basic Research Program of the Korea Science \& Engineering Foundation.

\section{References}

1. Annstrong, D. W: Schulte, G.: Schneiderheinze. J. M.: Westentherg. D. J. Anal Chem 1999.71. 5465.

2. Matsheka. M. I.: Elisha. B. G.: Lastovica. A. L.: On1. S. L. W. FEM IS Ificrobiol Lett 2002. 211. 17.

3. Tremoulet, f: Duche. O.: Namane, A:- Martine. B.: The European Listeria Genome Consortium. Labadıe. J. C. FEM IS Microbiol. Lett. 2002, 210.25.

4. Alexander. P.: Tomas. W. F J. Anal. Chem 1997.359. 198.

5. Vanderzant. C.: Splittsoesser. D. F. Compendium of Hethods for the Aforobiological Examination of Food. $3^{\text {td }}$ ed.: American Public Health Association: Washington. DC. 1992.

6. Johnson. J. L.: Rose, B. E.; Sharar. A. K; Ransom. G. M.: 
Lattuada. C. P.: MeNamara. A. M. M. J. Food Prot 1995, $58,597$.

7. Liu. Y.: Li. Y. Anal. Chem. 2001. 73.5180.

8. Yao. Z. P.: Demirev. P. A.: Fenselau. C. Anal Chem. 2002. 7t. 2529 .

9. Schneiderheinze. I. M: Armstrong. D. W: Schulte, G.: Westenberg. D. I. FEM S A ficrobilo. Lett. 2000. 189. 39.

10. Glvnn. I. R.: Belongia. B. M.: Annold. R. G.: Ogden. K. L. Baygents. J. C. Appl. Eninon. Microbiol. 1998. 64. 2572.

11. Kim. Y: Edward. S. Y. J. Chromatog A 1997. 781. 315.
12. Simo-alfonso, E.: Conti. M.; Gelfi. C.: Righetti, P. G. J. Chrontatog. A 1995.689 .85 .

13. Okun. V. M.: Ronacher. B.: Blaas. D.: Kenndler. E. Anal. Chem 1999. 71. 2028.

14. Schnabel. UT: Groiss. F; Blaas, D; Kenndler. E. Anal. Chent 1996. 68,4300

15. Shen, Y.: Berger, S. J.; Smith, R. D. Anal. Chem. 2000. 72. 4603.

16. Armstrong. D. W. He, L. Anal. Chem. 2001. 73. 4551.

17. Leclerc. H.: Moreau. A. FEIIS Mficrobilo. Review: 2002. 26. 207 